\title{
From a military seaplane base to an international circuit: a study of Toko Seaplane Base as a controversial heritage site
}

\author{
C. Y. $\mathrm{Tu}^{1} \&$ C. C. $\mathrm{Fu}^{2}$ \\ ${ }^{1}$ Department of History, National Cheng Kung University, Taiwan \\ ${ }^{2}$ Department of Architecture, National Cheng Kung University, Taiwan
}

\begin{abstract}
Located in a lagoon in south-western Taiwan, Toko (today's Dapeng Bay) was Taiwan's largest Japanese seaplane base during the Pacific War. After WWII, the infrastructures of Toko were reused as the R.O.C. Air Force schools until 1978. In 1997, Toko was designated as a National Scenic Area. However, Taiwan government failed to take advantage of this opportunity to turn it into a cultural heritage. Instead, it gave special permissions to a private company to operate the base, allowing the investors to demolish part of the barracks and to build an international circuit. This is the biggest BOT (Build, Operate, Transfer) project for the leisure industry in Taiwan so far, making Toko undoubtedly a controversial historical heritage site.
\end{abstract}

Keywords: adaptive reuse, seaplane bases, military heritage, Taiwan.

\section{Introduction}

Toko (today's Dapeng Bay), one of the largest inner bays in southwestern Taiwan, was the largest inland Japanese seaplane base during the Pacific War. Since 1940, this base has been sequentially stationed by Japanese navy air groups. After WWII, the infrastructures of Toko base were reused as R.O.C. Air Force schools until 1978 [23]. In 1997, Dapeng Bay was designated as a National Scenic Area. Since its establishment, this National Scenic Area rapidly emerged as a popular tourism and recreation destination. The Liouciou Special Scenic Area was incorporated into Dapeng Bay in 2000 [21]. On October 9, 2011, Penbay International Circuit officially opened. It is the first circuit track in Taiwan to satisfy FIA Grade 2 
standard and the track has hosted international events since 2012 [15]. The entire bay area is still under construction for the purpose of tourism.

Dapeng Bay is the biggest BOT (Build, Operate, Transfer) project for the leisure industry in Taiwan so far; however, the inappropriate policy of reusing makes it a controversial heritage site. This site, full of history while being compounded by a failed developmental dream, presents a great challenge for preservationists. Furthermore, the withdrawal of the military from regional area also leads to extremely adverse socio-economic consequences [11]. The purpose of this research is to discuss what the appropriate adaptive reuse policy should be applied in this case in order to carry out the potential of an abandoned military base and make it a catalyst when facing sustainable urban development.

\section{Literature reviews and case studies}

\subsection{Literature reviews}

Because the Japanese destroyed a huge amount of military records when WWII ended, it is very difficult to retrieve written materials about the history of the base and its military structures. Due to the lack of primary sources, researchers tried to rebuild the Dapeng Bay history in other ways.

$\mathrm{Tu}$, Fung-shien wrote an essay about the history of Dapeng Bay during the Japanese colonial period in 2000. Since his research focuses on the pre-war era, he didn't use the archives from either side of the war: Japan or the USA. He mainly relied on the sources from oral history. However, because all of the soldiers and navy pilots were Japanese, it's not easy to get correct data by visiting Taiwanese inhabitants living nearby the base [22].

$\mathrm{Tu}$, Cheng Yu published his research: "The History and Origination of Toko Seaplane Base" in 2013. Through the materials taking from the National Archives of the USA and Japan, he clarified that Toko Seaplane Base, built in 1938, was the largest seaplane base in Taiwan during the Pacific War. Since 1940, this base was sequentially stationed by Japanese navy air groups: Toko, 901st, 953rd, Ominato and 634th. Because of its strategic superiority, Toko was seriously bombed by the U.S. Navy Task Force 38, the 5th Air Force, and the 201st Aztec Eagles Mexican Fighter Squadron. This research laid the foundations of the history of Toko seaplane base [23].

The reuse of Dapeng Bay was still in a transferring process. This accounts for the fact that some researchers focused on giving suggestions and recommendations for the authority. Chu-lung Hsu used a combination of outdoor museum vision and tour guide system and focused on the operational mechanism when reusing historical space. He thought that the Dapeng Bay could be a perfect place for indepth tourism because there were many opportunities for further development. His essay analyzed the strengths and weaknesses of this site, while providing an outline and suggestions for future design and management. He also made a basic plan for organizing and maintaining historical culture in general [4].

Lin, Hui-Wen and $\mathrm{Fu}$, Chao-Ching elaborated the research by comparative studies, using examples from the abandoned navy base of Medway in the UK, the 
closure of foreign troops in Vauban, Germany, to the Alameda Naval Air Station in the USA to highlight reuse lessons. They saw these military bases as resources for sustainable city development. These cases show how former bases can be redeveloped and reused to incorporate public and private participants. They also consider the importance of evaluation during the planning process for a renewed reuse of the base. The cleanups and participation of local communities were also a driving force for the new development. Finally, this study explores the potential for using abandoned military sites as a catalyst to deliver sustainable urban development in small and medium sized cities. By valuating possibilities of military installation, the authors put special attention on the assessment of existing military properties [11].

\subsection{Case studies}

In this research, we take three congeneric cases as our focus of study. These cases show us how former military seaplane bases can be redeveloped and reused to incorporate public and private participants.

\subsubsection{HMS Daedalus, UK}

HMS Daedalus was used as an aircraft field around 1915. In 1917 this site became HM Naval Seaplane Training School, Lee-on-Solent, which was under the control of the Royal Naval Air Service (RNAS). In April 1918 the RNAS and the Royal Flying Corps (RFC) merged to become Royal Air Force (RAF) and the training establishment at Lee-on-Solent was transferred to the RAF, becoming No. 209 Training Depot Station and Admiralty designed hangars. The camp buildings were constructed in this period.

HMS Daedalus played a predominant role during WWII. Its operations included the D-Day landings. In the 1960s and 1970s, the training function of HMS Daedalus was gradually moved to other bases. HMS Daedalus closed in 1996 and had been identified as the best preserved seaplane base in Great Britain.

Influenced by the general characters of historic aviation sites, local planning authorities are required to exercise functions for preserving the character and appearance of the area when making the new redevelopment plan. By the master plan of some companies or professional associations, redevelopment of the Daedalus presents an opportunity for a variety of employment, leisure, commercial and residential uses. They also made recommendations for future management and the historic and architectural appraisals of the former HMS Daedalu base [5-7, 9, $10]$.

\subsubsection{Dinner Key, the USA}

Dinner Key, a small island in Biscayne Bay, was a training ground for the US Navy during World War I. Destroyed by the 1926 hurricane, the site was selected by the Pan American Airways for its Florida and Havana operations. During its construction in 1933, the Pan American Airways Terminal at Dinner Key, today's Miami City Hall, was not only the largest and most modern marine air terminal in the world, it was also the busiest commercial seaplane terminal in America. During World War II, Dinner Key again served as a base for the US Navy. In 1943, 
President Roosevelt arrived at Dinner Key to board for Casablanca. This is the first time that a U.S. President travelling in an aircraft while in duty. In August 9, 1945, Pan American ended the last flight to Dinner Key.

The site was purchased by the City of Miami in 1946 and was used as a waterfront park. In 1950, the Terminal Building was converted into a restaurant and marina office. In 1954 the building was adapted for reuse as Miami's City Hall. The four hangars were leased for marine use, such as maintenance, machine shops and an exhibition center. Behind the terminal building on Biscayne Bay is the Dinner Key Marina, serving more than 300 small boats. The authority invited the community and the Historic and Environmental Preservation Board to discuss the versatile reuses for the site and the buildings. The Pan American Seaplane Base and Terminal Building was listed in the National Register of Historic Places in $1974[14,18,26]$.

\subsubsection{Rathmines Park, Australia}

Rathmines was located in Lake Macquarie, NSW, Australia. In 1936, this land was chosen as a site for a flying boat base in the Newcastle region. The base started to operate in September 1939. Catalina flying boats, made by the U.S., arrived at Rathmines in February 1941, and was then converted for operational duties. The base served almost 3,000 officers in 1944-45, and was the largest flying boat base in Australia. During the Second World War, Rathmines was used as a ground training base and over 200 Catalina air crew were trained at the base. The base also provided a flying boat and marine service repair depot. After the war, Rathmines became the Officers' Training School on 12 April 1950 and in 1956 there were more than 230 buildings and structures in the base. However it ceased to operate as a seaplane base, the Rathmines base was closed in December 1960 $[1,8,16]$.

In 1962, the base was sold to Lake Macquarie Council. Many buildings were privately purchased and removed from the site or used by Lake Macquarie Council as community halls. The original Rathmines base has now been a heritage listed by the NSW State Government. The base has everlasting social significance to those who served during the WWII and to the community of Lake Macquarie, who recognizes the site's history and continues to use the site, creating an evolving landscape which retains significant elements of the RAAF Base. Lake Macquarie community showed great support and enthusiasm to the "Rathmines Catalina" project. They buy and maintained a Catalina, hoping to see a Catalina housed and operating from Rathmines on a waterway that is ideally suited for the historical sights, sounds and stories $[1,3,16]$.

\section{Concepts toward adaptive reuse}

\subsection{The definition and arguments of adaptive reuse}

Adaptive reuse is the process of recycling abandoned structures. This term came into mainstream historic preservation field during the 1960s and 1970s. It explores 


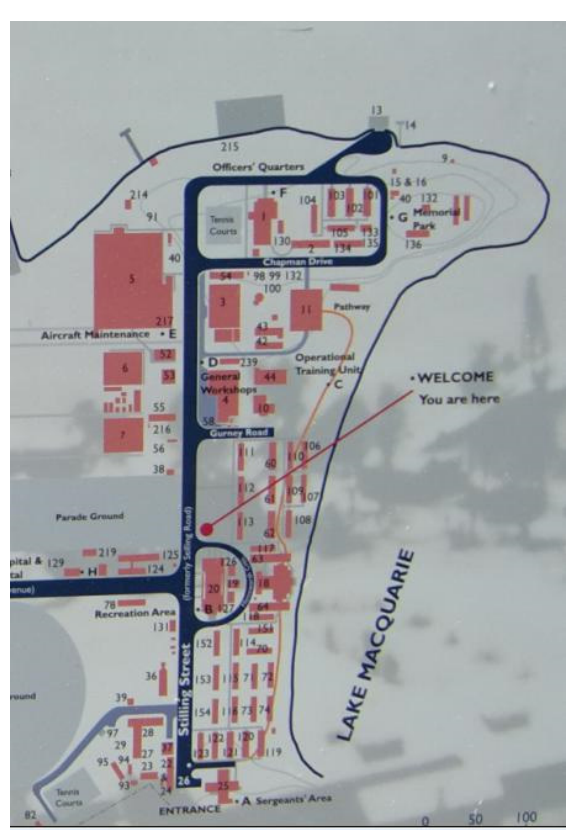

Figure 1: Current site plan of Rathmines Park. bulletin board in Rathmines Park.

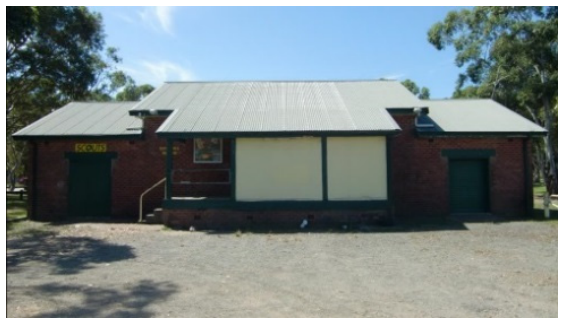

Figure 2: Inflammable liquids building; scout hall today.

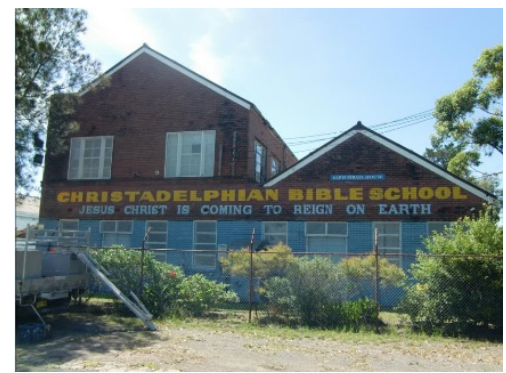

Figure 3: Former aircraft repair depot, the Christadelphian Bible School today.

the options between demolition and turning sites into museums. Adaptive reuse provides an opportunity to maintain heritage fabric, spaces and sites that might otherwise be lost and to make them available to new generations. Adding a new layer without erasing the earlier layers, the adaptive reuse process should become a part of the history of the site $[2,17,19]$.

According to Cantell, adaptive reuse of buildings has been an effective historic preservation strategy. It initially developed as a method of protecting historically significant buildings from demolition. Through renovation or sustainable deconstruction, these properties present a valuable resource. Adaptive reuse is now often interpreted as a process for economical uses. Many developers claim that residential developments are a matter of necessity [20].

In America, the Los Angeles Adaptive Reuse Ordinance even encourages developers to convert older buildings into new developments by providing incentives such as faster entitlements and reduced development fees. This will make available to developers in the residential-to-residential building conversion context. Young argued that the major argument voiced by opponents of this situation is just like the conversion of residential hotels to luxury lofts, which would expel a large number of lower income tenants and create more affluent tenants [13]. 
Although housing in some places has been criticized, its practicality is still the main strategic approach to adaptive reuse. When reusing vacant properties, American community development corporations would focus on the availability of affordable housing, community centers, park spaces and non-profit office space [17]. If we take Australia's Rathmines Park as examples, housing, leisure and community are indeed the main forms of reuse.

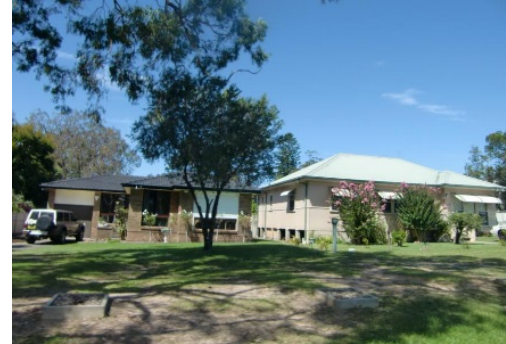

Figure 4: Private housing in Rathmines Park.

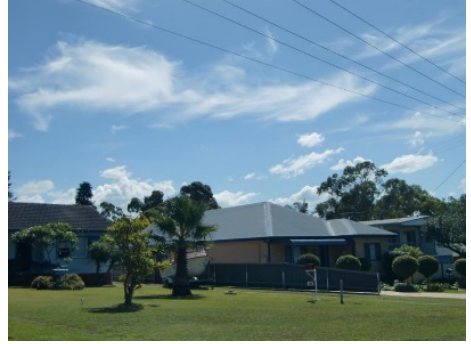

Figure 5: Private housing in Rathmines Park.

In the UK, the policy to redevelop military land is driven by the need to reduce government expenditure, to generate income, to promote government targets for brownfield (a land contaminated by decades of military or industrial activity with hazardous materials in soil or in the buildings) and to develop public housings [11, 20]. For example, affordable housing is the main pattern of re-development in Daedalus. Gosport Local Plan Review allocates 500 dwellings for the Daedalus site, 300 of which already have planning permission, with a residual allocation of $200[7]$.

\subsection{The prerequisites of adaptive reuse}

Adaptive reuse is not simply a matter of retaining the fabric of historical buildings. The heritage needs to be understood in complex ways including the spatial structures, the relationship between the site and its context, significant views to the site, and traces of processes [2]. Successful adaptive reuse projects usually require an advocacy strategy at both the state and local level. Large-scale redevelopment will likely require governmental involvement, but supports from the local community is also essential [17]. While studying the adaptability of the existing buildings to proposed new functions, we can't ignore the prerequisites in the designing process:

- Cultural significance of the building or groups of buildings;

- Legal protection instruments and implications (may have to undergo changes to reconcile realistically reuse with traditional old fashioned legislations);

- Views on buildings in question by local community and government agencies;

- Survey;

- $\quad$ Structural and architectural qualities corresponding to the proposed use(s);

- Location and accessibility; 
- Opportunities for financial support in planning/construction stages;

- Availability and procedures for purchase, leasing, permissions, zoning;

- Compatibility between building layout and the proposed use;

- Acquisition and allied costs, in particular when involving complex ownership - private, public, municipal, religious organizations, state, mixed, etc. including payments and compensations for relocations of residents;

- Physical conditions, including founding and structural condition; size, expansion possibilities, vertical, horizontal;

- Availability of utilities;

- Impact on surrounding buildings;

- Potential marketability of the new structure (both in free market economies and state-public economies) [19].

Through the re-evaluate examination accomplished in 2009, Lin and Fu pointed out that Dapeng Bay lost relevance to these prerequisites. For example, local, regional, national, and international identities of Dapeng Bay was not investigated and shaped, thus, it was not associated with any significant historical event or people which were worth commemorating. Although most of the installations on the site were dated between the 1930s and the 1940s, these buildings were not listed as either cultural heritage or historical buildings before 2007. Furthermore, the authority didn't make any renovation effort in this military base. Most of the installations remained in poor condition. Many of them were left deteriorating or even damaged without being repaired. That's why the buildings lack aesthetic value and no significant art could be found in this base [11].

\section{Dapeng Bay: a controversial heritage site}

\subsection{The current status of Dapeng Bay}

Military aviation sites are not only an important constituent of military cultural landscape, but are also reminders of the wartime conflicts. The promotion of numerous related publications, the emerging societies devoted to military history, and the establishment of military aviation museums in recent year testifies to the growing interest in military history. Therefore, in order to compromise the preservation of history practicality, most airfield structures could adapted to new purposes without harming their essential character. Except for residential development, many airfield structures are changed as, for example, barracks to offices, hangars to storage, base area to parking or servicing space [10].

What are the most common adaptive reuses for former military seaplane bases? Through the data of some websites such as Abandoned, Forgotten and LittleKnown Airfields in Europe, Abandoned and Little-Known Airfields, Wikipedia, we could identify the following findings:

- $\quad$ Australia: RAAF Base Rathmines - reuse as family housing units and heritage site;

- California: Hamilton Cove Seaplane Base -reuse as condominium complex;

- Treasure Island Naval Auxiliary Air Facility -reuse as family housing units; 
- Florida: Trumbo Point Seaplane Base -reuse as restaurant, bar and lounge, and vacation rental villas; Dinner Key Naval Air Facility - reuse as Miami City Hall;

- Venetian Causeway Seaplane Base - reuse as residential development;

- Great Britain: HMS Daedalus - reuse as residential development; Killingholme Naval Air Station, reuse as harbour, container storage, and import of cars;

- Island of Malta: Calafrana - reuse as harbour;

- Massachusetts: Ten Pound Island Coast Guard Air Station, mostly ruin - reuse as a lighthouse;

- Maryland: Whipp Seaplane Base - reuse as housing units;

- Rhode Island: Newport Naval Air Facility - reuse as Navy Exchange;

- Washington: Oak Harbor Naval Seaplane Base - reuse as a naval torpedo test facility; Sand Point Naval Air Station - reuse as the Warren G. Magnuson Park.

According to the practice exemplars that we have examined, the most common reuses are: (1) residential development: HMS Daedalus, Rathmines, Hamilton Cove, Treasure Island, Venetian Causeway, Whipp; (2) harbour: Killingholme, Calafrana; (3) recreation: Trumbo Point, Sand Point; (4) government related: Dinner Key, Gould Island; (5) storage: Navy Exchange.

Although Dapeng Bay belongs to the recreation field, its current status is different from others. In 1997, Dapeng Bay was designated as a National Scenic Area by Taiwan government (Tourism Bureau). But, the government failed to take advantage of this opportunity to turn it into a cultural heritage site. Instead, it gave special permissions to a private company to operate the base covering the land, sea, and air for 50 years, which also allowed the company to demolish part of the barracks, and to build an international circuit, a hotel, clubs, yacht wharfs, and beach recreation facilities. The Penbay International Circuit opened to public in 2011.

This case is the biggest BOT (Build, Operate, Transfer) project for the leisure industry in Taiwan so far. However, the authority neglected the noise pollution around the area, disregarded opinions from local community and did not show respect to its military significance. The whole site was almost turned into a huge circuit. Some of the buildings were razed by the company. During the weekends, racing drivers accelerate their vehicles in high speed and make loud and shrill sounds. Although 8 buildings were designated in 2007 as "Historical Building" under the protection of the Cultural Heritage Preservation Act, their conditions are poor, even severely weathering. Even worse, some of the designated historical buildings are located between the auto racing tracks, which prohibits cultural heritage visitors to visit them without buying entrance tickets for sitting in the auditorium.

\subsection{The lesson learned from the case of Dapeng Bay}

Although the damage done to these military installations can never be recovered, some scholars still regard this case as the most successful and impressive BOT 


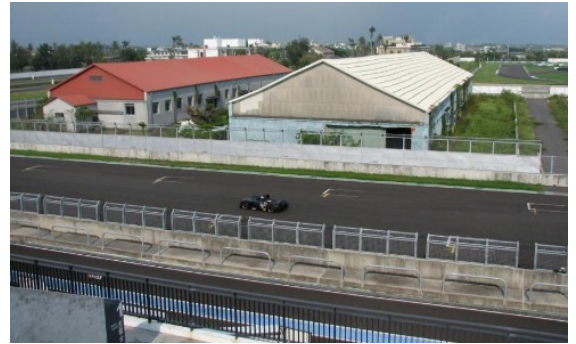

Figure 6: Penbay International Circuit, former Toko seaplane base, 2014.

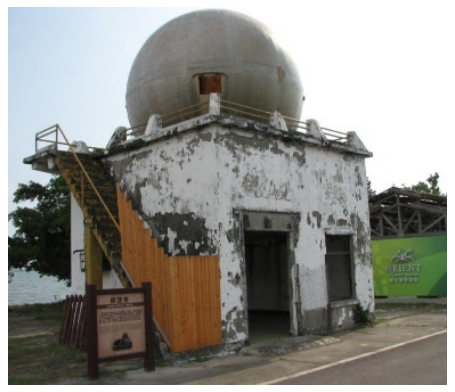

Figure 8: Radio Station, 2014.

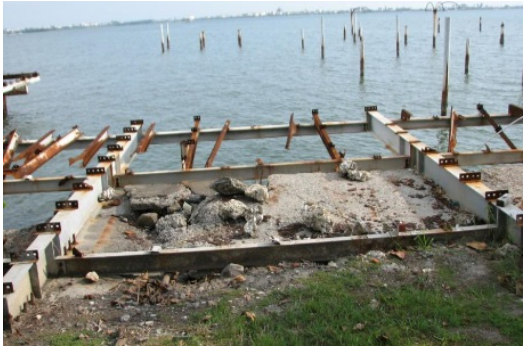

Figure 7: Seaplane Duck, 2014.

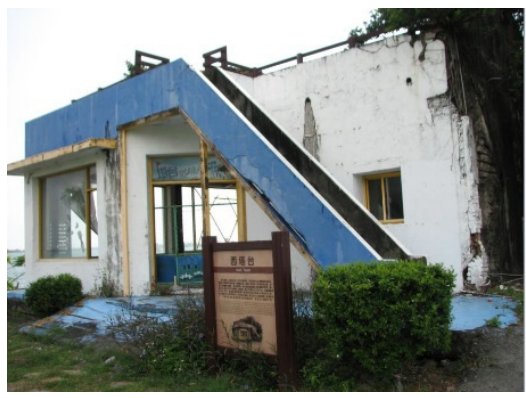

Figure 9: Western Operations Tower, 2014.

project in Taiwan. Liu argued that Dapeng Bay has acquired the most financial inputs from both the private investors and the government in terms of BOT projects, and its success came from developing potentials, enhancing communications, utilizing regional resources, supplying public facilities and services, insuring BOT operators' financial stability, increasing visitors' satisfactions, implementing successful marketing plans and striving for the government's supports [12]. Wang indicated that because investment benefit of a project is essential to attract private enterprises, the government should eliminate or reduce the limits imposed on the qualification for private investors. With respect to development mode, government should give private investors flexibility for proper adjustment [25].

For the Tourism Bureau, they probably think the policy is pragmatic, which helps saving government's budgets and leading to major construction projects which offers employment opportunities for local communities. Nevertheless, the government didn't integrate historic preservation into the development plan. The principles of adaptive reuse or heritage tourism were neglected in this case. How did this happen? Since 1978, Council for Economic Planning and Development set up a recreation development plan that would change Dapeng Bay into an aquatics recreation area. In the1970s, preservation was not a common sense 
in Taiwan. Lacking competent authority and legal protection, this military heritage was turned to be today's National Scenic Area.

Cultural Landscape has become a new category added in Cultural Heritage Preservation Act in Taiwan amended in 2005. A cultural landscape should be managed for the balance among change, developments and the essence features [24]. If Dapeng Bay could be designated as a cultural landscape, we believe an appropriate reuse of this site would appear. However, the BOT contract was signed by both sides in 2004. As a controversial heritage site, the case of Dapeng Bay should make us learn from it and find a way to contain, manage or even prevent it from recurring.

\section{Conclusion}

How to conserve defense heritage? What is adaptive reuse for a former military seaplane base? In order to answer these questions, we collected congeneric cases, such as Daedalus Conservation Area, UK, Dinner Key, US and Rathmines Park, Australia for a comparative study of the transitional process and reuse policy as well as the appropriate conservation methodology for defense heritage.

Since the developer has already turned Dapeng Bay into an international circuit and lacerate the historical fabrics belong to the site, the only thing we can do is to learn from this case, making it a reminder of the great emphasis that we should put on preservation issues in the future.

\section{References}

[1] A/C Serial No. A2-4 Section 2B, NO.73/A/426, Royal Air Force Museum: London, 2012.

[2] Adaptive reuse of industrial heritage: opportunities \& challenges. Heritage Council of Victoria: Melbourne, 2013.

[3] Catalina Flying Boat returns to Rathmines, ACN: 103492440, Catalina Flying Memorial Ltd: Macquarie Park.

[4] Chu-lung Hsu, In Reuse of Space to Military Facilities-A case Study of Dapeng Bay Military Camp. Graduate Institute of Urban Development and Architecture, National University of Kaohsiung: Kaohsiung, pp. 1-102, 2007.

[5] Daedalus Conservation Area appraisal. Gosport Borough Council: Gosport, 2007.

[6] Daedalus, Lee-on-Solent, historic environment baseline report. Forum Heritage Services: Wimborne, 2007.

[7] Daedalus masterplan proposals. LDA Design Consulting LLP: London, 2010.

[8] Doug Saxon, Rathmines Air Force Base 1939- 1960, a brief history. http://www.librarything.com

[9] Daedalus waterfront heritage statement. Forum Heritage Services: Wimborne, 2007.

[10] Historic military aviation sites conservation management guidance. English Heritage: London, 2003. 
[11] Lin, Hui-Wen, Fu, Chao-Ching, Discussion on approaches for reusing unused military base in Dapeng Bay Scenic Area, Taiwan. International Symposium on Religion, Culture \& Wetland Tourism, Dapeng Bay National Scenic Area: Ping Tung, pp. 1-24, 2009.

[12] Liu, Kun Yu, A Study of the Successful BOT Operation of the Dapeng Bay National Scenic Area, Department of Physical Education, Health \& Recreation, National Chiayi University: Chiayi, 2005.

[13] Matthew A. Young, Adapting to adaptive reuse: comments and concerns about the impacts of a growing phenomenon. Southern California Interdisciplinary Law Journal, 18(3), pp.703-728, 2009.

[14] Pan American Seaplane Base and Terminal Building designation report. City of Miami: Miami, 1993.

[15] Penbay International Circuit, http://www.pic-taiwan.com/en_region_ list.php

[16] Rathmines and the Catalina. RAAF Radschool Association Magazine, 24, pp. A-H, 2008.

[17] Recycling America: Adaptive Reuse in the 21st Century. http://law.duke.edu/sites/default/files/clinics/cec/cote.pdf

[18] Sarah Eaton, Pan American Airways System Terminal Building (Miami City Hall, HABS Ho. FL-36; Marina Building), City of Miami Planning Department Miami: Florida, 1981.

[19] S. Mutal, Adaptive reuse for the future development of the historic centres, some thoughts and considerations, Handout, 7, pp.1-7.

[20] Sophie Francesca Cantell, The adaptive reuse of historic industrial buildings: regulation barriers, best practices and case studies, Department of Urban and Regional Planning, Virginia Polytechnic Institute and State University: Virginia, 2005.

[21] Tourism Bureau, Republic of China (Taiwan). Dapeng Bay National Scenic Area, http://eng.taiwan.net.tw/m1 .aspx?sNo=0002122\&id=484

[22] Tu, Fung-shien, The exploration of Japanese Toko Military Base. The Taiwan Folkways, 50(2), pp. 107-133, 2000.

[23] Tu, Cheng Yu, The history and origination of Toko Seaplane Base. The Taiwan Folkways, 63(4), pp. 57-92, 2013.

[24] Wang, Chun-His, The Conservation and Management of "Cultural Landscape" within the Scope of Cultural Heritage. Department of Architecture, National Cheng Kung University: Tainan, 2014.

[25] Wang, Lung Chi, Contractor Selection Requirements of Sightseeing BOT Project - the Case of Tapeng Bay National Scenic Area. Department of Construction Engineering, The National Kaohsiung First University of Science and Technology: Kaohsiung, 2005.

[26] William E. Brown, Jr., Pan Am: Miami's wings to the World. The Journal of Decorative and Propaganda Arts, 23, Florida Theme Issue, pp. 144-161, 1998. 